\title{
Selective, weighted morphological research, by dividing the equipment for biocompost production by submorphologies
}

\author{
Mihai Olan ${ }^{1}$, Anişsoara Păun ${ }^{1}$, Paul Găgeanu ${ }^{1}$, Nicoleta Ungureanu $^{2 *}$, George Bunduchi ${ }^{1}$ \\ and Alexandru Zaica ${ }^{1}$ \\ ${ }^{1}$ National Institute of Research - Development for Machines and Installations Designed to Agriculture \\ and Food Industry - INMA Bucharest, Ion Ionescu de la Brad no. 6, sector 1, Romania \\ ${ }^{2}$ University Politehnica of Bucharest, Department of Biotechnical Systems, Splaiul Independentei no. \\ 313 , sector 6, Romania
}

\begin{abstract}
This paper describes the use of the method of selective, weighted morphological research by dividing by inventics submorphologies to analyze the equipment for biocompost production. The selective morphological research method was used to find the optimal constructive solution which is then developed in the research, design and testing of an innovative piece of equipment. Using Bellman's principle and the method of morphological analysis, the known constructive solutions will be studied, their weighting will be achieved by dividing by submorphologies and the Bellman diagram will be constructed to determine the weighting coefficient of the optimal solution.
\end{abstract}

\section{Introduction}

The determination of the optimal AoE solution, maximal, is made starting from Bellman's principle according to which "an optimal policy has the property that whatever the initial state and initial decision are, the remaining decisions must constitute an optimal policy with regard to the state resulting from the first decision."

The increasing amount of organic waste generated in cities is a major problem for the environment and human health, and one of the solutions to solve this problem is the composting technology. The recovery of organic waste produced in kitchens in the production of compost is very important [1]. The first research in this regard was carried out in 1926 in Austria, where an industrial station was built for the transformation of urban organic waste into compost.

Composting is a biological, aerobic process of controlled decomposition of organic waste with the help of microorganisms [2], through which compost, a product similar to humus and extremely useful for horticulture and agriculture, is obtained $[3,4]$.

\footnotetext{
* Corresponding author: nicoletaung@yahoo.com
} 
Composting reduces or prevents the release of methane into the atmosphere. It is estimated that methane released by the decomposition of organic matter is 26 times stronger than carbon dioxide [5], both being greenhouse gases that affect the environmental sustainability.

Composting technology involves several stages and takes place under controlled conditions, as it requires the regulation of $\mathrm{pH}$, temperature and moisture [6], as well as a correct mixture between materials rich in carbon and nitrogen [7].

Bian et al. (2019) [8] studied the composting technology on a pilot scale, using several mixed waste recipes (agricultural waste, including manure, vegetable leaves and rice husks in a mass ratio of $6: 3: 1$ ). Their study aimed to determine the influence of temperature and bioconversion time on composting performance, evaluated by the content of moisture, nutrients and carbon, respectively the $\mathrm{C} / \mathrm{N}$ ratio of compost. The optimal parameters were obtained at $75 \pm 5^{\circ} \mathrm{C}$ and 18 hours, and the obtained compost met the requirements of the quality standard.

If the compost pile contains manure, this particular organic waste can favor the heating of the compost due to the activity of decomposing microorganisms. It is recommended that the moisture in the compost pile be $60 \%$ and the temperature sould be between 65 and $70^{\circ} \mathrm{C}$ $[9,10]$. To obtain a quality compost, the aerobic fermentation technology at high temperatures requires periodic analysis of the maturity of the compost before its application as an organic fertilizer [11].

The extraction of mono-fertilizers from the compost as well as the odours capture technique can contribute to the improvement of the technical characteristics of the composting [12]. The addition of activators to the raw materials can improve the nutritional quality of the compost [13].

A methodology for the design and manufacture of portable organic waste shredders that can be used in compost production, respectively the factors that influence the shredding process of organic waste was analyzed by Ajinkya et al. [14].

To create an efficient equipment to loosen the compost, deductive logical methods of technical creation can be used by researching the known systems by the method of weighted, selective morphological research, with division by submorphology.

The aim will be to increase the degree of objectivity in choosing the optimal variant and thus an $\mathrm{ABCD}$ morphology is divided into the morphologies $\mathrm{AB}, \mathrm{BC}, \mathrm{CD}$, and to combine biasassemblies from each submorphology, each biasamblation is denoted by a subunit coefficient so that the sum of the coefficients on a line be equal to the number 1 , a technique similar to the decision technique imposed in value engineering [15].

In the case of equipment for biocompost production, there is the following classification in forming assemblies:

A- the basic structure of the equipment;

$\mathrm{A}_{1}$ - fixed equipment (Fig. 1);

$\mathrm{A}_{2}$ - mobile equipment.

$\mathrm{B}$ - movement system of the equipment;

$\mathrm{B}_{1}$ - towed equipment;

$\mathrm{B}_{2}$ - self-propelled equipment with diesel engine;

$\mathrm{B}_{3}$ - self-propelled equipment with electric drive;

$\mathrm{B}_{4}$ - self-propelled composting equipment.

$\mathrm{C}$ - drum construction:

$\mathrm{C}_{1}$ - with fixed knives:

$\mathrm{C}_{2}$ - with removable knives;

$\mathrm{C}_{3}$ - with drum welded supports and removable knives.

D - adjustment of working depth:

$\mathrm{D}_{1}$ - side leg with height-adjustable wheel and fixed drum; 
$\mathrm{D}_{2}$ - side leg with fixed height wheel and height adjustable drum.

$\mathrm{A}_{3}$ - construction of the drum with knives.

a. According to the type of actuation - the forming assembly B:

$\mathrm{A}_{1}$ - towed equipment;

$A_{2}$ - self-propelled equipment with diesel engine;

$\mathrm{A}_{3}$ - self-propelled composting equipment.

A1 - Fixed equipment for compost aeration. The Big Dutchman system (Fig. 1) is an innovative system that allows easy handling, automatic process control, easy adaptability to the amount of material to be composted, quick and easy installation. The final product is a valuable fertilizer that can be used in horticulture and agriculture.

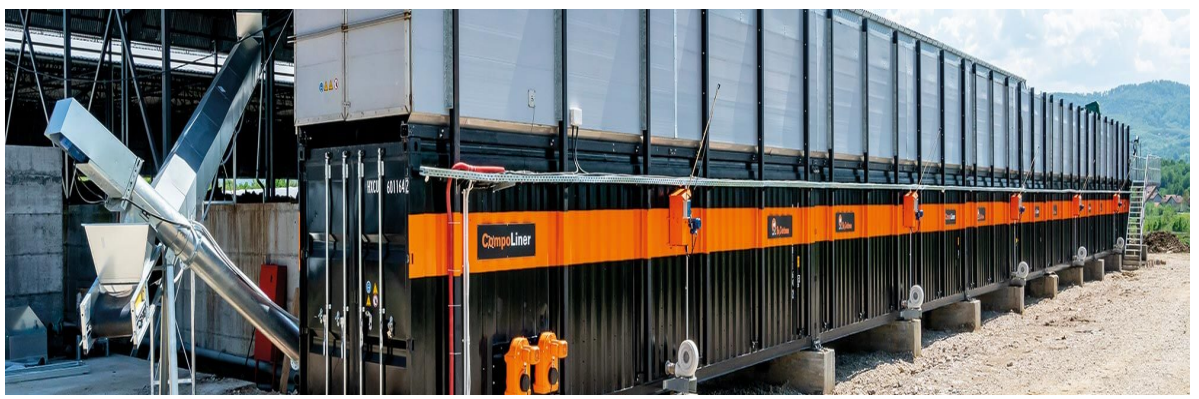

Fig. 1. Big Dutchman equipment [16]

$B_{1}$ - Towed equipment. SNDBERGER (Germany) manufactures towed equipment for compost aeration, the transition of the system from the transport position to the working position is achieved by folding the mixing drum frame with a hydraulic system (Fig. 2).

$B_{2}$ - Self-propelled equipment with diesel engine. The Crawler Type Compost Turner equipment (Fig. 3) has the direction made with two levers with which it can turn left or right and can return to $180^{\circ}$, the height of the drum with knives being adjusted hydraulically, so that the equipment can loosen piles of compost of max. $1.5 \mathrm{~m}$, the width of the resulting compost pile being $6 \mathrm{~m}$.

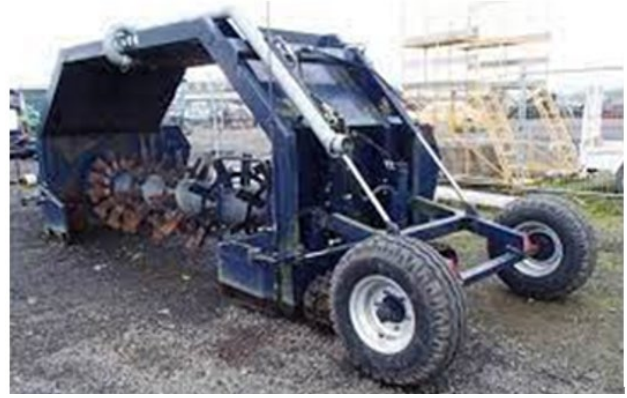

Fig. 2. SNDBERGER equipment [17]

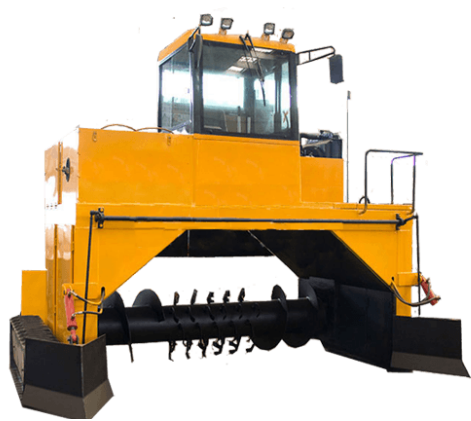

Fig. 3. Crawler Type Compost Turner equipment [18]

B $_{3}$ - Self-propelled equipment with electric gearmotor. The CMC SF 200 equipment (Fig. 4) made by the Austrian company Compost Systems Gmbh has electromechanical actuation for moving and rotating the drum with knives and achieves a good loosening of the compost material on fixed platforms. 
$B_{4}$ - Self-propelled composting equipment. WILDCAT has developed a new type of equipment - self-propelled, a construction machine equipped with hydraulic lifting and loading systems. The WILDCAT compost turner model type LS117A (Fig. 5) has a folding side wheel and the drive of the drum with a separate heat engine, being moved by a tractor with its own heat engine.

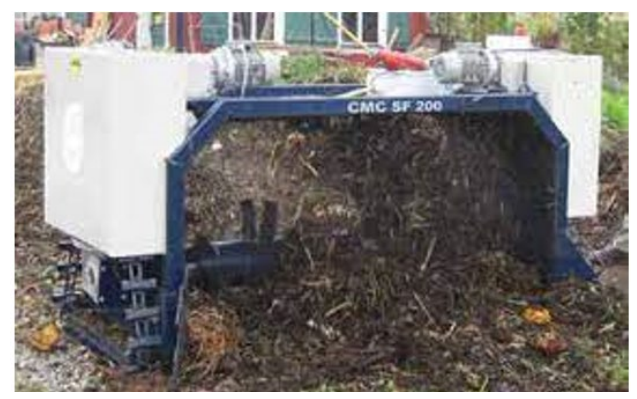

Fig. 4. CMC SF 200 equipment [19]

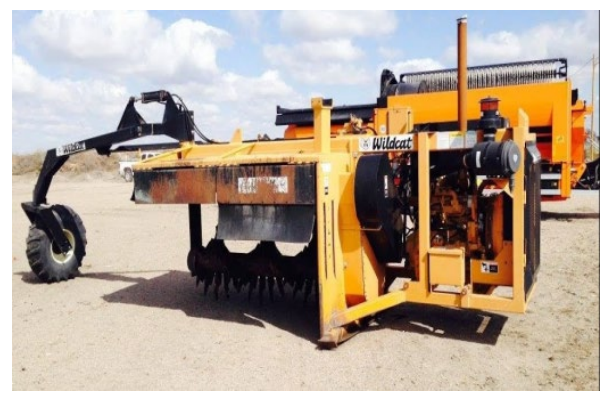

Fig. 5. WILDCAT compost turner equipment, model LS117A [20]

\section{Material and method}

To increase the degree of objectivity in selecting the optimal solution, the morphology $\mathrm{ABCD}$ is subdivided into submorphologies $\mathrm{AB}, \mathrm{BC}, \mathrm{CD}$. To compare the biasassemblies in each submorphology, each assembly is estimated with a subunit coefficient, so that the sum of the coefficients of on a line to be equal to 1 , a technique similar to the decision technique imposed by value engineering [21].

The appreciation criterion for establishing the weighting coefficients is the ratio between the productivity and the cost price of the analyzed equipment.

$\begin{array}{lcccccccc} & \mathrm{B}_{1} & \mathrm{~B}_{2} & \mathrm{~B}_{3} & \mathrm{~B}_{4} & & \mathrm{C}_{1} & \mathrm{C}_{2} & \mathrm{C}_{3} \\ \mathrm{~A}_{1} & 0 & 0 & 1 & 0 & \mathrm{~B}_{1} & 0,1 & 0,4 & 0,5 \\ \mathrm{~A}_{2} & 0,1 & 0,3 & 0,4 & 0,2 & \mathrm{~B}_{2} & 0,2 & 0,4 & 0,4 \\ & & & & & \mathrm{~B}_{3} & 0,1 & 0,3 & 0,6 \\ & & & & & \mathrm{~B}_{4} & 0,3 & 0,3 & 0,4 \\ & \mathrm{D}_{1} & & \mathrm{D}_{2} & & & & & \\ \mathrm{C}_{1} & 0,5 & 0,5 & & & & & \\ \mathrm{C}_{2} & 0,4 & 0,6 & & & & & \\ \mathrm{C}_{3} & 0,7 & 0,3 & & & & \end{array}$

The decision variables for each section are noted as $\mathrm{x}_{0}, \mathrm{x}_{1}, \mathrm{x}_{2}, \mathrm{x}_{3}$ :
$\mathrm{X}_{0}: \mathrm{A}_{1}, \mathrm{~A}_{2}, \mathrm{~A}_{3}$
$\mathrm{X}_{1}: \mathrm{B}_{1}, \mathrm{~B}_{2}, \mathrm{~B}_{3}, \mathrm{~B}_{4}$
$\mathrm{X}_{2}: \mathrm{C}_{1}, \mathrm{C}_{2}, \mathrm{C}_{3}$
$\mathrm{X}_{3}: \mathrm{D}_{1}, \mathrm{D}_{2}$

The following notations are made:

$\begin{array}{ll}\mathrm{V}_{\mathrm{I}}\left(\mathrm{x}_{0}, \mathrm{x}_{1}\right) & \text { - the share of biasassemblies } \mathrm{A}_{0} \mathrm{~A}=1 \\ \mathrm{~V}_{\mathrm{II}}\left(\mathrm{x}_{1}, \mathrm{x}_{2}\right) & \text { - the share of biasassemblies } \mathrm{AB}, \\ \mathrm{V}_{\mathrm{III}}\left(\mathrm{x}_{2}, \mathrm{x}_{3}\right) & \text { - the share of biasassemblies } \mathrm{BC},\end{array}$


$\mathrm{V}_{\mathrm{IV}}\left(\mathrm{x}_{3}, \mathrm{x}_{4}\right) \quad$ - the share of biasassemblies $\mathrm{CD}$,

The total share of tetrasemblies will be:

$$
\mathrm{F}\left(\mathrm{x}_{0}, \mathrm{x}_{1}, \mathrm{x}_{2}, \mathrm{x}_{3}\right)=\mathrm{V}_{1}\left(\mathrm{x}_{0}, \mathrm{x}_{1}\right) * \mathrm{~V}_{1 \mathrm{II}}\left(\mathrm{x}_{1}, \mathrm{x}_{2}\right) * \mathrm{~V}_{1 \mathrm{II}}\left(\mathrm{x}_{2}, \mathrm{x}_{3}\right) * \mathrm{~V}_{1 \mathrm{~V}}\left(\mathrm{x}_{3}, \mathrm{x}_{4}\right)
$$

\section{Results and discussion}

In the first stage, the starting point is considered in $A_{0}$ and the maximum weight of the $\mathrm{AB}$ bias assemblies will be calculated according to the formulas:

$$
\begin{array}{ll}
\mathrm{F}_{1}\left(\mathrm{~B}_{1}\right)=\operatorname{MAX}\left[\left(\mathrm{f}_{1}\left(\mathrm{x}_{1}\right) * \mathrm{~V}_{\mathrm{II}}\left(\mathrm{x}_{1}, \mathrm{~B}_{1}\right)\right],\right. & \mathrm{f}_{1}\left(\mathrm{x}_{1}\right)=1 \\
\mathrm{~F}_{1}\left(\mathrm{~B}_{2}\right)=\operatorname{MAX}\left[\left(\mathrm{f}_{1}\left(\mathrm{x}_{1}\right) * \mathrm{~V}_{\mathrm{II}}\left(\mathrm{x}_{1}, \mathrm{~B}_{2}\right)\right],\right. & \mathrm{x}_{1}=\mathrm{A}_{1} \mathrm{~A}_{2} \mathrm{~A}_{3} \\
\mathrm{~F}_{1}\left(\mathrm{~B}_{3}\right)=\operatorname{MAX}\left[\left(\mathrm{f}_{1}\left(\mathrm{x}_{1}\right) * \mathrm{~V}_{\mathrm{II}}\left(\mathrm{x}_{1}, \mathrm{~B}_{3}\right)\right],\right. & \\
\mathrm{F}_{1}\left(\mathrm{~B}_{4}\right)=\operatorname{MAX}\left[\left(\mathrm{f}_{1}\left(\mathrm{x}_{1}\right) * \mathrm{~V}_{\mathrm{II}}\left(\mathrm{x}_{1}, \mathrm{~B}_{4}\right)\right],\right. &
\end{array}
$$

By replacing the values it will be obtained:

$$
\begin{aligned}
& \mathrm{F}_{1}\left(\mathrm{~B}_{1}\right)=\operatorname{MAX}\left(-\infty \mathrm{x}_{1} \quad 0,1 \times 1\right)=0,1 \quad \mathrm{x}_{1}=\mathrm{A}_{2} \\
& \mathrm{x}_{1}=\mathrm{A}_{1} \quad \mathrm{x}_{1}=\mathrm{A}_{2}
\end{aligned}
$$

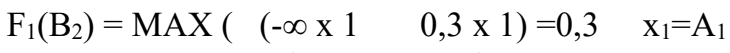

$$
\begin{aligned}
& \mathrm{x}_{1}=\mathrm{A}_{1} \quad \mathrm{x}_{1}=\mathrm{A}_{2} \\
& \mathrm{~F}_{1}\left(\mathrm{~B}_{3}\right)=\operatorname{MAX}(1 \mathrm{x} 1 \quad 0,4 \times 1)=1 \quad \mathrm{x}_{1}=\mathrm{A}_{1} \\
& \mathrm{x}_{1}=\mathrm{A}_{1} \quad \mathrm{x}_{1}=\mathrm{A}_{2} \\
& \mathrm{~F}_{1}\left(\mathrm{~B}_{4}\right)=\operatorname{MAX}(-\infty \mathrm{x} 1 \quad 0,2 \times 1)=0,2 \quad \mathrm{x}_{1}=\mathrm{A}_{2} \\
& \mathrm{x}_{1}=\mathrm{A}_{1} \quad \mathrm{x}_{1}=\mathrm{A}_{2}
\end{aligned}
$$
obtained:

The maximum weight of the $\mathrm{ABC}$ triasemblies is noted as $f_{\mathrm{I}, \mathrm{II}}\left(\mathrm{x}_{2}\right)$ and it will be

$$
\begin{array}{r}
f_{\mathrm{I}, \text { II }}\left(\mathrm{C}_{1}\right)=\operatorname{MAX}\left[f_{\mathrm{I}, \mathrm{II}}\left(\mathrm{x}_{2}\right) \times \mathrm{V}_{\mathrm{III}}\left(\mathrm{x}_{2} \mathrm{C}_{1}\right)\right] \\
\mathrm{x}_{2}=\mathrm{B}_{1}, \mathrm{~B}_{2}, \mathrm{~B}_{3}, \mathrm{~B}_{4} \\
f_{\mathrm{I}, \text { II }}\left(\mathrm{C}_{2}\right)=\operatorname{MAX}\left[f_{\mathrm{I}, \mathrm{II}}\left(\mathrm{x}_{2}\right) \times \mathrm{V}_{\mathrm{III}}\left(\mathrm{x}_{2} \mathrm{C}_{2}\right)\right] \\
f_{\mathrm{I}, \mathrm{II}}\left(\mathrm{C}_{3}\right)=\operatorname{MAX}\left[f_{\mathrm{I}, \mathrm{II}}\left(\mathrm{x}_{2}\right) \times \mathrm{V}_{\mathrm{III}}\left(\mathrm{x}_{2} \mathrm{C}_{3}\right)\right]
\end{array}
$$

By replacing the numeric values, it will be obtained:

$$
\begin{aligned}
& f_{\text {I, II }}\left(\mathrm{C}_{1}\right)=\operatorname{MAX}[0,1 \times 0,1 \quad 0,3 \times 0,2 \quad 1 \times 0,1 \quad 0,2 \times 0,3]=\operatorname{MAX}[0,01 \quad 0,06 \quad 0,1 \quad 0,6]=0,1 \\
& \mathrm{x}_{2}=\mathrm{B}_{1} \quad \mathrm{x}_{2}=\mathrm{B}_{2} \quad \mathrm{x}_{2}=\mathrm{B}_{3} \quad \mathrm{x}_{2}=\mathrm{B}_{4} \quad\left(\mathrm{x}_{2}=\mathrm{B}_{3}\right) \\
& f_{\mathrm{I}, \mathrm{II}}\left(\mathrm{C}_{2}\right)=\operatorname{MAX}[0,1 \times 0,4 \quad 0,3 \times 0,4 \quad 1 \times 0,3 \quad 0,2 \times 0,3]=\operatorname{MAX}\left[\begin{array}{llll}
0,04 & 0,12 & 0,3 & 0,06
\end{array}\right]=0,3 \\
& \mathrm{x}_{2}=\mathrm{B}_{1} \quad \mathrm{x}_{2}=\mathrm{B}_{2} \quad \mathrm{x}_{2}=\mathrm{B}_{3} \quad \mathrm{x}_{2}=\mathrm{B}_{4} \quad\left(\mathrm{x}_{2}=\mathrm{B}_{3}\right) \\
& f_{\mathrm{I}, \mathrm{II}}\left(\mathrm{C}_{3}\right)=\operatorname{MAX}[0,1 \mathrm{x} 0,5 \quad 0,3 \times 0,4 \quad 1 \mathrm{x} 0,6 \quad 0,2 \mathrm{x} 0,4]=\mathrm{MAX}\left[\begin{array}{llll}
0,05 & 0,12 \quad 0,6 \quad 0,08
\end{array}\right]=0,6 \\
& \mathrm{x}_{2}=\mathrm{B}_{1} \quad \mathrm{x}_{2}=\mathrm{B}_{2} \quad \mathrm{x}_{2}=\mathrm{B}_{3} \quad \mathrm{x}_{2}=\mathrm{B}_{4} \quad\left(\mathrm{x}_{2}=\mathrm{B}_{3}\right)
\end{aligned}
$$

In the case of tetraassemblies $\mathrm{ABCD}$, it will be obtained:

$f_{\text {I, II, III }}\left(\mathrm{D}_{1}\right)=\operatorname{MAX}\left[\mathrm{f}_{\mathrm{I}, \text { II, III }}\left(\mathrm{x}_{3}\right) \times \mathrm{V}_{\mathrm{IV}}\left(\mathrm{X}_{3} \mathrm{D}_{1}\right)\right]$

$f_{\text {I, II, III }}\left(\mathrm{D}_{2}\right)=\operatorname{MAX}\left[\mathrm{f}_{\mathrm{I}, \text { II, III }}\left(\mathrm{x}_{3}\right) \times \mathrm{V}_{\text {IV }}\left(\mathrm{X}_{3} \mathrm{D}_{2}\right)\right]$

By replacing the numeric values it will result:

$$
\begin{aligned}
& f_{\text {I, II, III }}\left(\mathrm{D}_{1}\right)=\operatorname{MAX}[0,1 \mathrm{x} 0,5 \quad 0,3 \times 0,4 \quad 0,6 \mathrm{x} 0,7]=\operatorname{MAX}[0,05 \quad 0,12 \quad 0,42]=0,42 \\
& \mathrm{x}_{3}=\mathrm{C}_{1} \quad \mathrm{x}_{3}=\mathrm{C}_{2} \quad \mathrm{x}_{3}=\mathrm{C}_{3} \quad\left(\mathrm{x}_{3}=\mathrm{C}_{3}\right) \\
& f_{\text {I, II, III }}\left(\mathrm{D}_{1}\right)=\operatorname{MAX}[0,1 \times 0,5 \quad 0,3 \times 0,6 \quad 0,6 \mathrm{x} 0,3]=\operatorname{MAX}[0,05 \quad 0,18 \quad 0,18]=0,18
\end{aligned}
$$




$$
\mathrm{x}_{3}=\mathrm{C}_{1} \quad \mathrm{x}_{3}=\mathrm{C}_{2} \quad \mathrm{x}_{3}=\mathrm{C}_{3} \quad\left(\mathrm{x}_{3}=\mathrm{C}_{2}=\mathrm{C}_{3}\right)
$$

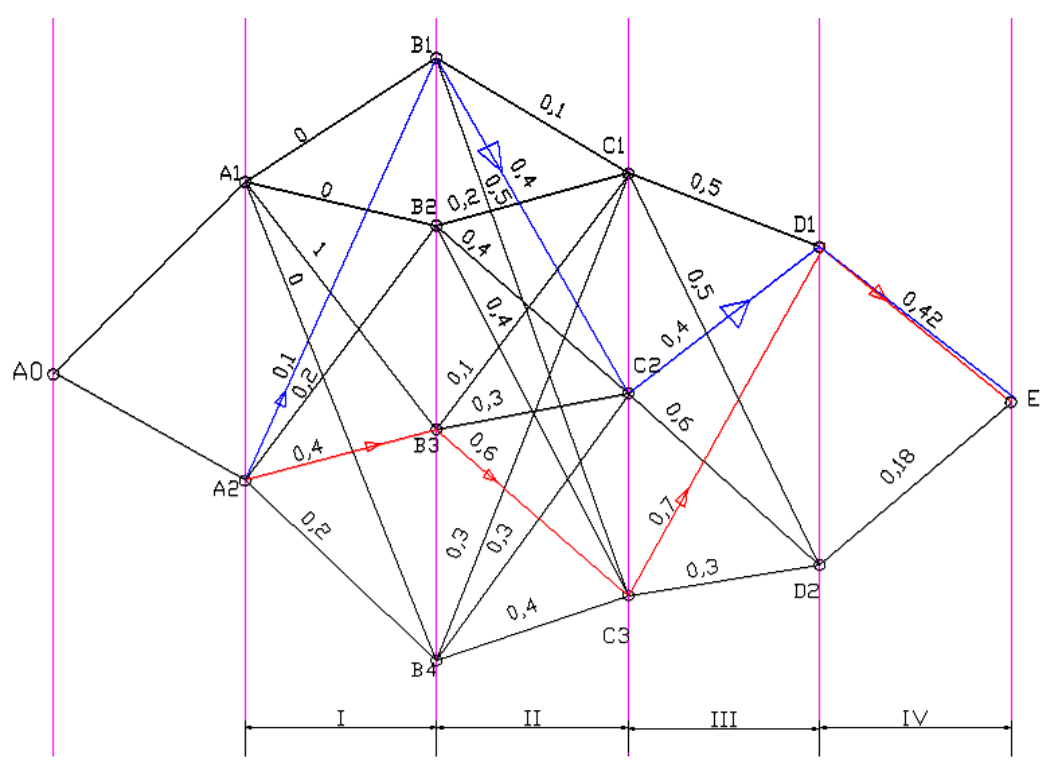

Fig. 6. Dots and arrows diagram

From these matrices will be constructed the diagram of "points and arrows" through the graph in Figure 6 [21].

\section{Analysis of possible constructive-functional variants} calculated:

After removing the incompatible assemblies, the representative assemblies are

1. $\mathrm{A}_{2} \mathrm{~B}_{3} \mathrm{C}_{3} \mathrm{D}_{1}=0,4 \mathrm{x} 0,6 \mathrm{x} 0,7 \mathrm{x} 0,42=0,07056$ - Self-propelled mobile equipment with electromechanical drive (gear motors), the drum has welded supports and removable knives.

2. $A_{2} B_{1} C_{3} D_{1}=0,1 \times 0,5 \times 0,7 \times 0,42=0,0147$ - Mobile towed equipment, the drum has welded supports and removable knives.

Based on a research contract, the two types of equipment were designed and a type of choice is to be executed and tested.

\section{Variant 1 - Self-propelled mobile equipment with electromechanical drive (gear} motors), the drum has welded supports and removable knives

This equipment consists of a support (1) with a drum with removable knives (2) and the drive of this drum is performed with a conical-cylindrical electric gearmotor (30). The movement of the system is done with two rubber tracks (4) and (5) driven by two electric gearmotors (6) and (7) which are controlled by an electrical panel (8). To increase the moisture of the compost to the set value, water pipe with spray nozzles (9) is used (Fig. 7).

This system has the following advantages:

- working autonomy - it does not require a tractor to move and drive the drum with knives;

- it has a drum with removable knives that can be replaced and resharpened in case of wear;

- it is an efficient, functional constructive solution and at a lower cost price than the imported equipment. 

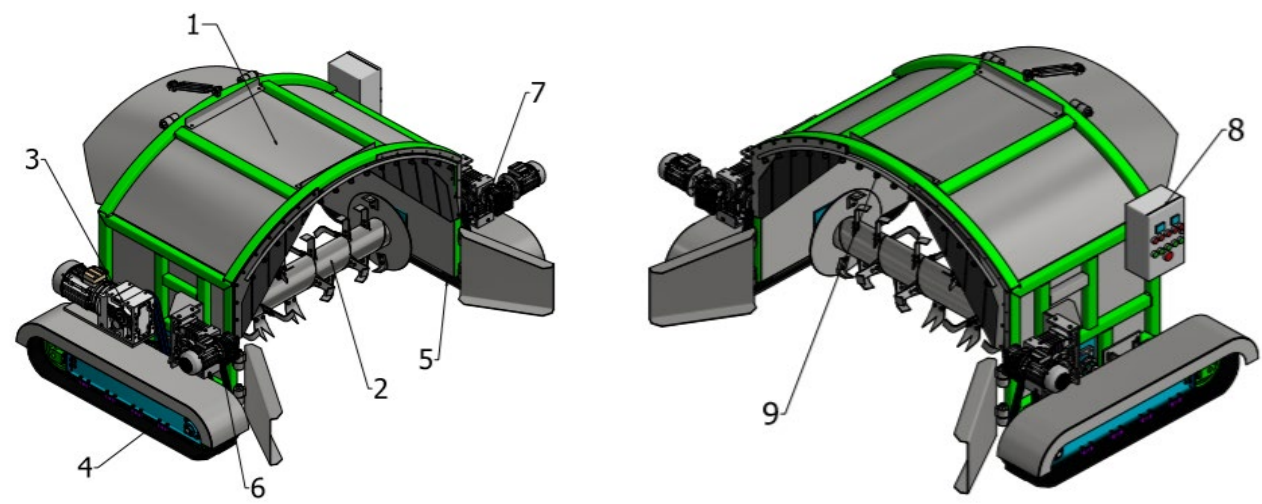

Fig. 7. Self-propelled equipment for biohumus production

Variant 2 - Mobile towed equipment, the drum has welded supports and removable knives

The system consists of a welded frame (1) on which is mounted a drum (2) with welded supports and removable knives. The equipment has a side wheel (3) that can be folded to $90^{\circ}$ while moving and an articulated frame (4) stiffened with two tie rods (5). The coupling of the equipment to the tractor is made with the lugs (6) and the drive is made with the cardan shaft (7) that transmits the rotational movement to the drum (2) by means of a Gall chain transmission (8), a conical reducer (9) and a cardan shaft (10). For directing the compost from the edges this equipment is provided with two orientation paddles (11) and for wetting the compost the system is provided with a pipe (12) with spray nozzles for water (Fig. 8).
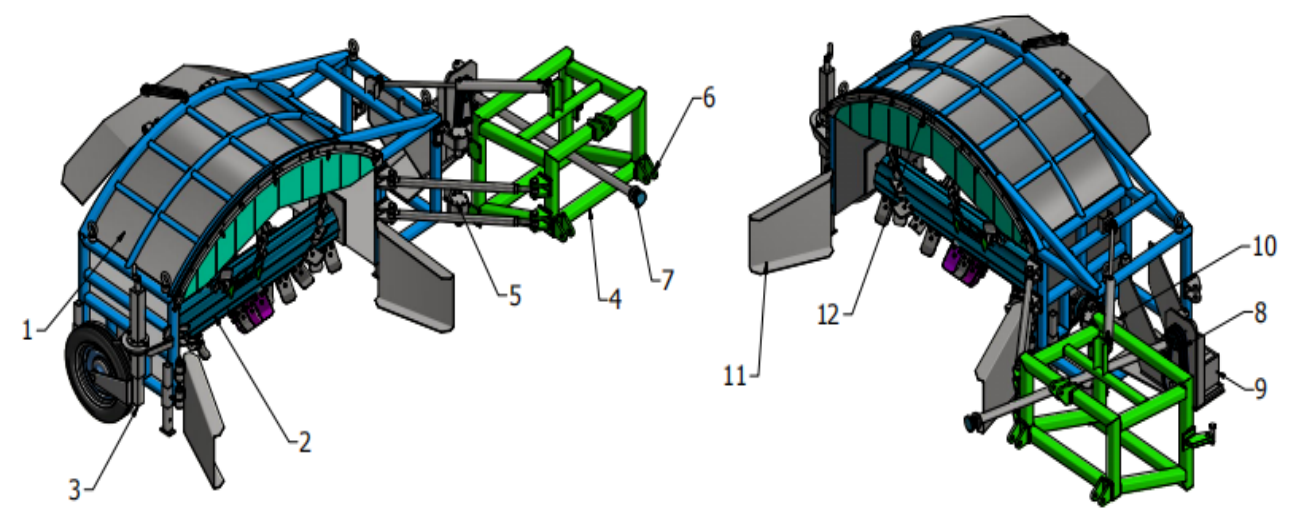

Fig. 8. Towed equipment for compost loosening

This system has the following advantages:

- low cost price, considering the work capacity offered and the degree of aeration;

- operational safety;

-the possibility of folding the entire system during transport and rotating the side wheel support that provides support during transport and during transport.

\section{Conclusions}

The analysis study of the technical solutions made by the companies with achievements in this field shows that there is a wide range of different equipment from a constructive point of view, but also from the production capacity.

Following the analyis of the main representative technical solutions available on the market and using the method of weighted, selective morphological research, with division by 
submorphology to analyze existing solutions and find new constructive-functional variants that will be then developed through the design-research activity, in the two representative types of equipment for biohumus production.

Using these results, two pilot installations were designed and executed, and the results obtained from the use of this equipment in compost production confirm the technical data provided from the design stage and demonstrate the usefulness of using this method of scientific research for research in this field.

This work was supported by a grant of the Romanian Research and Innovation Ministry, program Nucleu, PN 19100202 - CERCETĂRI PRIVIND REALIZAREA UNEI TEHNOLOGII DE PRODUCERE A BIOHUMUSULUI (VERMICOMPOST).

\section{References}

1. M. Diacono, A. Persiani, E. Testani, F. Montemurro, C. Ciaccia, Sustainability 11(14) (2019)

2. S. Singh, L. Nain, Proc. Indian Natl. Sci. Acad. 80 (2014)

3. C.O. Ijagbemi, S. Adepo, IOSR 4 (2014)

4. E.A. Laza, I.L. Caba, V. Vlăduţ, D.M. Bordean, At. Atanasov, Research People and Actual Tasks on Multidisciplinary Sciences, Lozenec, Bulgaria (2019)

5. C. Cristescu C., AGIR Publishing, Bucharest (2008)

6. V. Vlăduț, E. Marin, I. Voicea, L. Apostol, I. Găgeanu, M. Olan, D. Cujbescu, A. Pruteanu, Gh. Matei, N. Ungureanu, R. Oprescu, M. Dincă, B. Zăbavă, M. Catană, International Symposium ISB-INMATEH - Agricultural and Mechanical Engineering, Bucharest, Romania (2018)

7. I. Voicea, V. Vlăduț, M. Matache, D. Dumitru, S. Isticioaia, E. Trotuş, V. Arsenoaia, The $15^{\text {th }}$ Annual Meeting "Durable Agriculture - Agriculture of the Future", Craiova, Romania (2019)

8. B. Bian, X. Hu, S. Zhang, C. Lv, Z. Yang, W. Yang, L. Zhang, Bioresource Technol. 287 (2019)

9. S. Sutripta, Procedia Environ. Sci. 34 (2016)

10. A. Ameen, J. Ahmad, S. Raza, Int. J. Sci. Res. Publ. 6 (2016)

11. M. Zhang, S. Aiping, A. Muhammad, Y. Lihua, A. Muhammad, Biomass Convers. Biorefin. 3 (2021)

12. M. Toledo., J. Siles, M. Gutiérrez, M. Martín, M. Waste Manag. 76 (2018)

13. M.S. Ayilara, O.S. Olanrewaju, O.O. Babalola, O. Odeyemi, Sustainability 12(11) (2020)

14. S. Ajinkya, A. Hande, A. Deshpande, IJIRST 1(7) (2014)

15. V. Belous, Gh. Doncean, Performantica Publishing, Iasi (2001)

16. https://www.bigdutchman.com

17. https://www.i-bidder.com

18. https://compost-turner.net/

19. www.compost-systems.com

20. www.https://urcrecycle.com

21. T. Stanciulescu T., B. Vitalie, I. Moraru I., Performantica Publishing, Iasi (1998) 